\title{
Ethics in the State-Owned Companies in the Public Sector: A Thin Line between Corporate Governance and Ethical Leadership
}

\author{
Lufuno Nevondwe \\ Kola O. Odeku
}

Konanani Raligilia

Faculty of management and Law, School of Law, University of Limpopo, South Africa

Doi:10.5901/mjss.2014.v5n15p661

\section{Abstract}

\begin{abstract}
Ethics suggest that all persons are by nature moral as it would not be possible for humans to exist collectively or even individually without an innate ethical sense. In order for the public sector to thrive in business, the board of directors needs to be guided by ethics and take into account the abiding interests of humanity and the good of the public. It is argued in this paper that the abuse of power in the public sector has often been associated with unethical leadership and conducts which undermine the notion of Ubuntu. The irregularities which often arise in the awarding of tenders in the state-owned companies are some of the challenges facing the public sector. In order to address these challenges and promote a flourishing democracy, it is argued that ethical leadership as envisaged in the King III Report needs to be adhered to by the board of directors. This paper concludes that the direction and control of ethics in any organisation is vital especially where the line between corporate governance and ethical leadership has become blurred.
\end{abstract}

Keywords: Ethics, Corporate Governance, State-Owned Companies, Public Sector, Leadership, Ubuntu and Board of Directors.

\section{Introduction}

The South African Government, through its Department of Public Enterprises, (DPE) has made it clear that it expects State-Owned Companies (SOCs) to be run in line with strict corporate governance principles (Alphonse, 2011).

According to Mokoena (2005) there has been a lot of theories and information in the body of knowledge on the principles of good corporate governance and ethical leadership. Many countries have developed guidelines, codes and legislation on good corporate governance and ethics. In addition, many corporate governance programmes have been developed and used in the implementation of governance codes by many organizations and institutions (Aguilera and Cuervo-Cazurra, 2009). Regardless of all these corporate governance developments and implementation initiatives, many catastrophic corporate failures, caused by unethical individual behaviours and weak corporate cultures, still continue to this day (Solomon, 2007). These corporate failures have resulted in serious economic consequences with grave socio economic implications of job losses, loss of revenue by inland revenue, erosion of pension reserves and loss of investor confidence and so on (Holliday et al. 2009). Ethics is a very important pillar of leadership and if it is applied properly in all the governance structures, it can yield results leading to good governance that promotes responsibility, transparency and accountability ( Székely and Knirsch, 2005).

\section{Objective}

The objective of this paper is to define the word ethics and its application in the running of the business of SOCs and also to articulate how the board of directors can tackle ethical issues when performing their fiduciary duties as outlined in the Companies Act, 2008 and King Reports on Corporate Governance. To achieve this objective, the paper evaluates the literature on ethics, corporate governance, corporate ethics and values, ethical leadership in SOCs within the public sector, as outlined in King III Report and ubuntu principle.

\section{Motivation and Significance of the Study}

The study contributes significantly to the debate regarding the ethics in SOCs and a thin line drawn between corporate 
governance and ethical leadership. The paper makes adequate recommendations to the challenges faced by SOCs in implementing ethics as per the Code, King III, Companies Act and other relevant legal prescripts. The study will benefit board of directors in SOCs by making them aware of the importance and relevance of establishing Social and Ethics Committee with their SOCs board of directors.

\section{Methodology}

The methodology for this paper involved the application of qualitative data that are illustrative of the impact of derivative and team misconducts that form the crux of this study. The traditional method of citation, analysis of cases and other sources are the main scientific methods in legal scholarship. This article is concerned primarily with the impact of the abuse of power in the state-owned companies as a result of unethical leadership.

\section{Literature Review}

The focus of this paper is basically on the upholding of the ethical values by the management leadership in the SOCs. As the broader concept of ethics is not clearly defined (Erasmus and Wordsworth, 2004), over the years, it has not been easy for the law makers and scholars to come up with the precise definition of ethics.

Against this background, Komba and Vermaak (2012) attempted to define ethics concept to mean "a set of rules that define right and wrong conduct and that help individuals distinguish between fact and belief, decide how such issues are defined and what moral principles apply to the situation." The emphasis of this definition echoed the attribute of Llyod and Mey (2010) that unethical employees, in this case managers will hamper a company's attempts to become globally competitive. Retaining unethical employees at the helm of the SOCs directorship is suicidal to the management of the company and may consequently results in the low morale of the subordinates at the grassroots level.

Similarly, subordinate may be encouraged by their leaders within the SOCs who subscribe to ethical rules, this will impact honesty and trust in the company, promoting positive outcomes for competitiveness (Joseph, 2000). It is therefore in the light of Joseph's assertion that indeed the application of ethics forms the crux of good governance. The observance of ethics is becoming more important as communities begin to realise its significance (Lloyd and Mey, 2010). According to Schoeman (2014), ethics should encompass all issues that are pertinent to accountability and transparency in the SOCs as this will serve as a guiding tool in the policy development within the company.

MacDonald (2010) asserts that "ethics can be defined as the critical, structured examination of how we should behave-in particular, how we should constrain the pursuit of self-interest when our actions affect others." MacDonald further urges that "for practical purposes, ethics means providing reasoned justification for our choices and behaviour when it affects others, and reasoned justification for our praise or criticism of other people's behaviour."

While Verlaquez (1987) define ethics as a branch of philosophy which seeks to address issues related to concepts of right and wrong. It is sometimes referred to as moral philosophy and can be broadly divided into four subject areas which are meta-ethics, descriptive ethics, normative ethics and applied ethics (reference). In their attempt to define ethics, Verlaquez et al. (1987) drew attention to two things that should not be considered as ethics. They suggest that ethics is not necessarily acting in accordance with one feeling as sometimes a person's feelings about a particular issue may lead them to act in a way that is unethical. Ethics cannot also be equated with religion because although most religions advocate and provide incentives for people to act in an ethical manner, ethics applies to everyone whereas religion is limited to certain groups of people (Singer, 2011).

According to Khoza (2012) there is a leadership imperative that compels adherence to sound ethics as ethics is a pillar for good leadership in the society. Khoza (2013) further urges that "Ethics" and "Morality" are concepts which are often used interchangeably or as synonyms: an ethical issue is a moral issue. To an increasing degree, though, the term "Ethics" is applied to specialised areas of morality, such as medicine, business, the environment and so on. In good business practice, where professionals are involved, a governing body will typically draw up a "Code of Ethics" for its members (Khoza, 2013). "Ethics" in this sense can be viewed as a subset of morality concerned with the moral obligation relating to the practice of a profession or discipline. On the other hand, some philosophers, from Socrates to Bernard Williams, use "ethics" in a broad sense to refer to reflective answers to the question: "How do I live?" "What is my cardinal sense of bad and good?" If we accept this broad sense of "ethics", then morality becomes a subset of ethics concerned with obligation.

The building foundation towards the restructuring of SOCs was mainly to entail new, creative and diverse strategies for genuine empowerment (Ministry of Public Enterprises, 2000). This restructuring was meant to develop strategies for an alternative service delivery that include broadened ownership, training, procurement and self- 
management opportunities for black people, women and the disabled, through direct involvement in SOC s management (Ministry of Public Enterprises, 2000). Regrettably bad leadership, which is evidence in the regularly exposed in the media for misconduct, has not made this aim of restructuring to be realised. (Schoeman, 2014). Irregularities in the awarding of tenders resemble greater deal of corruption and fraud in SOCs and it has become a scourge within the bureaucratic administration in South Africa. This may be as a result of the fact that politicians may be having an upper hand in the direction of these SOC (Vavi, 2014). This sentiment was also echoed by Vavi (2014), the Secretary General of the Congress of South African Trade Unions (COSATU) in his letter to the Chairperson of the South African Broadcasting Corporation Board setting out the federation's concerns. Vavi argued that the leadership battles at the SABC and the absence of any consistent leadership at the top filters down into the staff, whose excellent work often keeps being undermined by lack of clear lines of command combined with uncertainty about the future (Vavi, 2014). Some of the concerns raised by Vavi was that since 2007, the SABC has had three Boards of Directors, two interim boards, six CEOs, resignations by board members, serious allegations of corruption and waste of resources.

According to Mbo and Adjasi (2013:6), political leaderships are usually under the pretence that they are serving the public, however, their primary interest while in office is to serve themselves and their collaborators. Consistency in governance and ethical leadership skills plays a pivotal role in the professional relationship with politicians (Mafunisa, 2012:84). It must be borne in mind that the public must be seen to be having the total trust and confidence in the corporate governance of SOC's which serves as the vehicle to the South African developmental state (Thomas, 2012:449).

Towards this end, and on the question of corruption and bribery, a number of companies refer to a code of conduct and many SOCs have an ethics hotline as measures to alleviate any form of ethical transgressions (Hamman and Schild, 2008). These guidelines, as espoused by Schoeman (2014) can ensure that a company's code of ethics is a welldesigned element of its management of ethics that makes a positive contribution towards creating an ethical workplace.

\section{Legal Business Frameworks in South Africa}

The South African SOCs were previously regulated by the Companies Act 46 of 1926 and Companies Act 61 of 1973 and now, they are currently regulated by the new Companies Act 71 of 2008. Prior to the New Companies Act of 2008 coming into effect, the Government of South Africa in 1999 introduced a restructuring policy framework known as the Accelerated Agenda towards the Restructuring of the State Owned Enterprises. This policy framework was designed to enable Government to co-ordinate thinking on how to restrict and contain the excesses of SOC's. It also aimed at improving corporate governance and ensuring ethics and probity.

The other important legal framework is the King Code of Governance Principles (the Code) and the King Report on Governance for South Africa (King III) which was published on 1 September 2009 and became effective on 1 March 2010 (King 2010). It is therefore important to note that all these reports, King I, King II, and e King III are aimed at promoting good corporate governance in South Africa (Andreasson, 2011). However, King III report on corporate governance became necessary because of the new Companies Act no. 71 of 2008 and changes made in international governance trends ( Ackers, 2009). Now the King III boldly declared that it applies to all entities regardless of the manner and form of incorporation or establishment, whether in the public, private sectors or non-profit sectors (Fikelepi, 2011).

The Companies Act, No 71 of 2008 being the driver of good corporate governance in South Africa was signed by the President on 8 April 2009 and gazetted in Gazette No. 32121 (Notice No. 421) (Nagdee. 2013). This Act replaces the Companies Act, 61 of 1973 and came into effect on 1 May 2011. Section 34(1) of Companies Act, No 71 of 2008 provides that "In addition to complying with the requirements of this Part, a public company or SOC must also comply with the extended accountability requirements set out in Chapter 3." Chapter 3 deals with the enhanced accountability and transparency of companies including the state-owned companies.

However, it remains to be seen how the policy framework on Restructuring of State Owned Enterprise in South Africa of 2012 will address the issue of good governance (Ewelukwa, 2011). This is mainly due to the fact that one of the reasons necessitating the large scales restructuring of the public enterprises is the failure of organs of state on good governance (van Basten, 2007). Therefore, the main aim is to ensure there is proper oversight to contain and curtail excesses in order to reduce corruption and fraud so that the broader stakeholders and the society can benefit (Werther and Chandler, 2010). The remainder of this paper will deal with issues relating to what constitute corporate governance and the influence of corporate ethics and value in corporate governance. Lastly the paper will deal with the ethical leadership as broadly outlined in King III report. 


\section{What is Corporate Governance?}

Corporate governance is about how companies are directed and controlled (Kahan and Rock, 2007). "It is concerned with holding the balance between economic and social goals and between individual and communal goals. The aim is to align as nearly as possible, the interests of individuals, corporations and society" (King, 2002).

According to Thomson et al (2009), corporate governance refers to the set of systems, principles and processes by which a company is governed. They provide the guidelines to how the company can be directed or controlled such that it can fulfil its goals and objectives in a manner that adds to the value of the company. It is also beneficial for all stakeholders in the long term. Stakeholders in this case would include everyone ranging from the board of directors, management, shareholders to customers, employees and society. The management of the company hence assumes the role of a trustee for all stakeholders (Thomson, 2009).

According to Peters (2004), corporate governance is based on relationships. It is about people interacting with other people. It is about people interacting with products and technology and people interacting with systems. Governance at heart is about human nature.

Nevondwe (2012) opined that corporate governance is generally understood to mean the way companies are directed and controlled such that it can fulfil its goals and objectives in a manner that adds to the value of the company and is also beneficial for all stakeholders in the long term, Thus, the emphasis is on those organs which play a vital role in corporative decision-making (John and Senbet, 1998: 371- 403) Corporate governance is based on principles such as conducting the business with integrity and fairness, being transparent with regard to all transactions, making all the necessary disclosures and decisions, complying with all the laws of the land, accountability and responsibility towards the stakeholders and commitment to conducting business in an ethical manner (Rossouw, 2005:94-106).

From the above explanation, it can be said that corporate governance had been originally associated with the companies thus, having a domain in the company law (Gilson, 2001). Company law is essentially concerned with: making available the corporate form to facilitate and regulate the process of raising capital (corporate finance or capitalisation of a company); and, secondly, imposing controls on persons whose power is derived from the finance that the users of the corporate form have put at their disposal (Nevondwe, 2012:16).

\section{Corporate Ethics and Values and their Influence on Corporate Governance}

Business ethics is concerned with good and bad or right and wrong behaviour and practices that take place within the business context ( Crane and Matten, 2010). Concepts of right and wrong are increasingly being interpreted today to include the more difficult and subtle questions of fairness, justice, and equity ( Tota and Shehu, 2012). Values are the individual's concepts of relative worth, utility, or importance of certain ideas. One's values, therefore, shapes one's ethics (Carroll \& Buchholtz, 2003).

According to Khoza (2013), business ethics is one of the areas of applied ethics. The application of morality to business is as old as business and morality themselves. The rise of business ethics as an identifiable subject of study took place in the USA in the 1970's and in Europe, Australia and other countries in Asia, Africa and South America.in the late 1980s.

Business ethics grapples with the moral justification of business structures and practices (Khoza, 2013). As corporations are a dominant feature of the free enterprise system, much work has focussed on the structures, governance, responsibilities and activities of corporations. In this regard, business ethics deals with the moral responsibilities and rights of individual managers and employees (Khoza, 2013).

According to Landman (2002), "ethics are not an optional extra or a discretionary add-on to normal business. We do not first set up and manage a marketing function devoid of ethics, only to consider adding ethics as an afterthought when we run into difficulties with misleading advertisements or irate customers. Another example is that we do not first develop a financial investment product and then ask whether it is ethical. The product itself, together with our disclosure or nondisclosure to the public, is in essence an ethical process. In short, ethics are woven into the fabric of the business."

Be that as it my, Thompson and Strickland (2003) argued that a strong corporate culture founded on ethical business principles and moral values is a vital driving force behind continuous strategic success (for example, implementation of a corporate governance programme). Many executives are convinced that a company must care about how it does its business, otherwise the company's reputation, and ultimately its performance, is put at risk (Fombrun et al. 2010).

They argue that corporate ethics and values programs are not window dressing, they are typically undertaken to create an environment of strongly held values and convictions to make ethical conduct a way of life (Sims and Felton, 
2006). Moral values and high ethical standards nurture the corporate culture in a very positive way - they connote integrity, "doing the right thing," and genuine concern for stakeholders. Value statements serve as a cornerstone for culture building; a code of ethics serves as a cornerstone for developing a corporate conscience (SIMS, 2005).

\section{Ethical Leadership as Outlined in King III}

The underlying philosophy of the King III Report revolves around leadership, sustainability and corporate citizenship (Cassim et al. 2011). On the issue of leadership, the King III Report requires the board of directors to provide effective leadership based on ethical foundation (Dubrin, 2012). Ethics or integrity is the foundation of and reason for corporate governance (Brown, 2005). An ethical corporate culture constitutes more than social philanthropy or charitable donations (Zadek et al. 2013). The reasoning behind the ethics of corporate governance, which requires the board of directors to ensure that the company is run ethically, is that, as this is achieved, the company would earn the necessary approval from those affected by and affecting its operations ( Walker and Sego 2008).

The court found Ubuntu-botho is deeply rooted in our society. These values should assist in informing corporate decisions made by directors in state owned enterprises. Proper and constructive dialogue would enable better outcomes in the decision making process. This form of governance is underpinned by the philosophy of ubuntu-botho. The time is right to incorporate the views of umuntu ngumuntu ngabantu in the King code of good governance

The court further ruled that integrity is a key principle underpinning good corporate governance. Good corporate governance is based on a clear code of ethical behaviour and personal integrity exercised by the board, where communications are shared openly. There are no opportunities in this environment for cloaks and daggers. Important decisions are not made in haste or in anger. There must be ethical behaviour in dealings with fellow board members. These dealings must be dealt with in such a manner to ensure due process and sensitivity (paragraph 64 of the judgement).

The Constitution of the Republic of South Africa recognises the importance of good governance (Ashton, 2006). Section 195 deals with basic values and principles governing public administration (Dorasamy, 2010). In terms of this section, there must be a high standard of professional ethics. In fact, this standard must be promoted and maintained. These principles apply to organs of state and public enterprises (section 195(2) of the Constitution).

This is not surprising, given the history and the advent of the new South Africa democratic era. The Constitution compels government in all of its forms, both through government departments and organs of state (including state-owned enterprises) to adhere to principles of good governance (Hart, 2002). State-owned enterprises such as the SABC are included in the definition of "organ of state." It is for this reason that the provisions of the Constitution as well as the legislation enacted in terms thereof are applicable to state-owned enterprises (Goodman Brothers (Pty) Ltd v Transnet Ltd 1998 (4) SA 989 (W). The Constitution has enshrined certain rights that also have a direct bearing on the corporate governance of state-owned enterprises.

The Public Finance Management Act No. 1 of 1999 as amended was promulgated to give effect to Chapter 13 of the Constitution. According to the then Minister of Finance, Trevor Manuel, the aim of this Act is to modernise the system of financial management in the public sector (Manuel, 2003). It represents a fundamental break from the past regime of opaqueness, hierarchical systems of management, poor information and weak accountability. The Act will lay the basis for a more effective corporate governance framework for the public sector.

The Constitution imposes a number of general obligations on all organs of state to promote cooperative government (Chaskalson, 2000). In particular, organs of state involved in intergovernmental disputes are required to make every effort to settle the dispute and exhaust all other remedies before approaching the courts (Okpaluba, 2003). This does not prevent organs of state seeking relief from the courts and is therefore a workable model (Khoza and Adam, 2005).

In state-owned enterprises, like other organisations, good corporate governance is ultimately about effective leadership (Vaughn and Ryan, 2006). An organisation depends on its board to provide it with direction, and the directors need to understand what that leadership role entails (Van den Berghe and Levrau, 2004). The Power of Governance correctly set out that the concept of leadership in state-owned enterprises is not always understood. The learned authors set out at page 49: "in the case of state-owned enterprises, this problem may be magnified: here one needs to consider the respective roles not only of the Board and management, but also the role of government as a shareholder. It is critical that there is an understanding by government, in its capacity as shareholder, of its leadership role in directing and guiding the state-owned enterprise. The concept of a shareholder performance agreement can assist in clarifying the respective roles of the Board and shareholder ... The solution begins with a proper understanding of what leadership means to the Board and to the shareholder." 
In the light of this court decision, this paper remarks that the shareholder performance agreement may enhance the ethical capacity of the board members in the performance of their duties. In so doing, this would be in the interests of the shareholders of the very same state-owned companies that the board is serving.

\section{Conclusion}

The King III report is the major role player in the quest for good governance in the South African SOCs. A lot of the discussion was also on the challenges that this concept of good governance brought in SOCs through literature consultation and policy frameworks.

This paper examined the concept of ethics and its influence in the corporate governance and eventually established that an ethical value forms the heart of good governance in SOCs. Government policy proposals and other legal frameworks were discussed at great lengths on the issues of upholding these ethical values at the leadership level of the enterprises.

Towards the end, the paper examined the spirit of ubuntu as conclusively relevant to good governance in SOCs. This spirit is therefore serving as a guiding tool towards the ethical conduct of the leadership or board members of these companies.

\section{Recommendations}

Having discussed the concepts of corporate governance and ethical leadership within the broader context of ethics at great length, the paper recommends that the government should come up with solutions to bad corporate governance if it wants SOCs to be managed efficiently. This can be realised if the government develop a policy which will incorporate the spirit of ubuntu, as it has been suggested above in the content of this paper into governance ethical values.

In order to curb bad corporate governance, this paper recommends that any unethical conduct must be dealt with, irrespective of whether the member of the board is politically designated to seat in the board of these SOCs

All SOCs must develop a Code for Ethics that will address all the questions and problems related to ethics. All SOCs must be encouraged to have Social and Ethics Committee as a subcommittee of the Board of SOCs.

\section{References}

Ackers B 2009. Corporate social responsibility assurance: how do South African publicly listed companies compare? Meditari Accountancy Research, 17(2):1 - 17.

Aguilera RV, Cuervo-Cazurra A 2009. Codes of Good Governance. Corporate Governance: An International Review, 17(3): 376-387.

Alphonse A 2011. Mining in the South Pacific. From http://www.roland-seib.de/05/Seib-Pressespiegel-1.5.11.pdf. (Retrieved on 24 September, 2013).

Andreasson S 2011. Understanding Corporate Governance Reform in South Africa Anglo-American Divergence, the King Reports, and Hybridization. Business \& Society, 50(4):647-673.

Ashton PJ, Patrick MJ, MacKay HM, Weaver AVB 2006. Integrating biodiversity concepts with good governance to support water resources management in South Africa. From http://www.ajol.info/index.php/wsa/article/view/5135. (Retrieved on 26 January 2014).

Brown MT 2005. Corporate integrity: Rethinking organizational ethics and leadership. Cambridge, UK:Cambridge University Press.

Chaskalson A 2000. Human Dignity as a Foundational Value of Our Constitutional Order. South African Journal on Human Rights, 16:193-2004.

Corporate and Commercial/King Report on Governance for South Africa- 2009/Introduction and Background pp1-118 at 2. Available online at http://www.library.up.ac.za/law/docs/king111report.pdf (accessed on 18 June 2014)

Crane A, Matten D 2010. Business ethics: Managing corporate citizenship and sustainability in the age of globalization. Oxford University Press, Oxford, UK.

Dorasamy N 2010. The impact of the global crisis on ethical leadership: A case study of the South African public sector. African Journal of Business Management, 4(10):2087-2096.

Dubrin A 2012. Leadership: Research findings, practice, and skills. Ohio, USA: Cengage Learning Products.

Erasmus BJ and Wordsworth R 2004. Aspects of Business Ethics in South Africa. South African Journal of Labour Relations, 28(2) 77112.

Ewelukwa UU 2011. South-South Trade and Investment: The Good, the Bad and the Ugly - African Perspectives, Minnesota journal of International Law, 20:513-522.

Fikelepi UN 2011. Guiding principles on building sustainable SOEs in South Africa. From http:/www.repository.up.ac.za /handle/2263/23805. (Retrieved on 21 February, 2013).

Fombrun CJ, Gardberg NA, Barnett ML 2000. Opportunity Platforms and Safety Nets: Corporate Citizenship and Reputational Risk. 
Business and Society Review. 105(1):85-106.

Gilson RJ 2001. Globalizing Corporate Governance: Convergence of Form or Function. The American Journal of Comparative Law, 49(2): 329-357.

Hamman R and Schild C. 2008. Business and Human Rights in South Africa: Context and Recommendations for Pro-active Engagement by the National Business Initiative. Environmental Evaluation Unit, 1-23.

Hart GP 2002. Disabling globalization: Places of power in post-apartheid South Africa. California, USA: University of California Press.

Hendricks PSA and Wyngaard RG 2010. South Africa's King III: A Commercial Governance Code Determining Standards of Conduct for Civil Society Organizations. International Journal of Civil Society Law, 8:176-184.

Holliday CO, Schmidheiny S, Watts P 2002. Walking the talk: The business case for sustainable development. Sheffield, UK:Greenleaf Publishing Ltd.

Implementing the Municipal Finance Management Act, 2003. http://mfma.treasury.gov.za/mfma/guidelines/introductory\%20guide\%20 revised.pdf. (Retrieved on 14 July, 2013).

John Kand Senbet LW 1998. Corporate Governance and Board Effectiveness, Journal of Banking and Finance 22(4): 371- 403.

Joseph J 2000. Ethics in the Workplace. From http://www.asaecenter.org/Resources/articledetail.cfm?ltemNumber=13073 (Received on June 18, 2014).

Kahan M, Rock EB 2007. Hedge Funds in Corporate Governance and Corporate Control. University of Pennsylvania Law Review, 155(5): 1021-1093.

Khomba J.K and Vermaak FNS 2012. Business ethics and corporate governance: An African socio-cultural framework. African Journal of Business Management, 6(9):3510-3518.

Khoza and Adam in The Power of Governance, (2005), Pan MacMillan and Business in Africa: Johannesburg.

Khoza R 2013. Ethics and Business Leadership, an address to SAICA. From http://www.bing.com/search?q=ethics+and+business+ leadership,+an+address+to+saica\&form=cmdtdf\&pc=cmdtdf\&src=ie-searchbox\&adlt=strict. (Retrieved on November 16, 2013).

Khoza R 2012. Attuned Leadership (African Humanism as Compass). From http://penguin.bookslive.co.za/blog/2012/01/16/podcast-drreuel-khoza-unpacks-attuned-leadership-african-humanism-as-compass/. (Received on June 18, 2014).

King ME 2010. The synergies and interaction between King III and the Companies Act 61 of 2008: enforcement and regulatory regime: part IV. From http://reference.sabinet.co.za/sa_epublication_article/ju_jur_2010_a23. (Retrieved on 11, June, 2013).

Knirsch M 2005.Responsible Leadership and Corporate Social Responsibility: Metrics for Sustainable Performance. European Management Journal, 23(6):628-647.

Lloyd HR, Mey MR 2010. An ethics model to develop an ethical organisation. From http://sajhrm.co.za/index.php/sajhrm /article/view/218/265. (Retrieved on May, 12).

MacDonald C 2010. The Business Ethics Blog. From http://businessethicsblog.com/. (Retrieved on 11 March, 2013).

Mafunisa MJ 2008. The role of codes of conduct in promoting ethical conduct in the South African public service. South African Journal of Labour Relations, 32(1):81-92.

Manuel T 2003. Modernising Financial Governance. From http://mfma.treasury.gov.za/mfma/guidelines/introductory\%20guide \%20revised.pdf (Retrieved on 17 July, 2013).

Mbo M, Adjasi C 2013. Drivers of Organizational Performance: A State-Owned Enterprise Perspective. From http://www.bing.com/search?q=drivers+of+organizational+performance\%3a+a+state-owned+enterprise+perspective\&form $=$ cmdtdf\&pc=cmdtdf\&src=ie-searchbox\&adlt=strict. (Retrieved on 22 May, 2014).

Mokoena LD 2005. The importance of corporate ethics and values building a sustainable strategy model for effective implementation of good corporate governance within a state-owned enterprise in South Africa. From http://uir.unisa.ac.za/bitstream/handle /10500/164/2005\%20MBL\%203\%20Research\%20Report\%20LD\%20Mokoena\%20Full\%20Report.pdf?sequence=1. (Retrieved on 19 August, 2013).

Mokwena T 2012. Restructuring of State Owned Enterprise in South Africa. From http://www.dpe.gov.zal . (Retrieved on 29 December, 2013).

MPE 2002. Ministry of Public Enterprises Republic of South Africa. Policy Framework on An Accelerated Agenda Towards the Restructuring of State Owned Enterprises. From http://www.bing.com/search?q=policy+framework+on+an+accelerated+ agenda+towards+the+restructuring+of+state+owned+enterprises\&form=cmdtdf\&pc=cmdtdf\&src=ie-searchbox\&adlt=strict. (Retrieved on 24 October, 2013).

Nagdee Z 2013. An assessment of the institutional functionality of accounting practice in South Africa. From https://152.106.6.200/handle/10210/8567. (Retrieved on 27 February, 2014).

Nevondwe L 2012. Corporate Governance Principles: Lessons to be learnt. The Thinker Political Journal (44):16-21.

Okpaluba C 2003. Justiciability, constitutional adjudication and the political question in a nascent democracy: South Africa (part 1). South Africa Public Law, 18(2):331-348.

Peters G 2004. Cascading Good Governance through the Organisation. From http://www.your-call.com.au/information/documents/ Cascadinggoodgovernance.pdf. (Retrieved on 24 February, 2013).

Rossouw GJ 2005. Business Ethics and Corporate Governance. Business Society , 44(1): 94-106.

Schoeman C 2012. Ethical Leadership in the Public Sector. Directorship, 2:9-14.

Schoeman C 2014. How to Crack your Company's Code of Ethics: The Five Fundamental Factors Influencing Critical Documents. From http://www.ethicsmonitor.co.za/How-To-Crack.aspx. (Retrieved on 24 March, 2014).

Sims RR 2005. Restoring ethics consciousness to organizations and the workplace. Succeeding in the Private, Public, and Not-for-Profit. 
New York, USA: M.E Sharpe Incorporation.

Sims RR, Felton EL 2006. Designing and Delivering Business Ethics Teaching and Learning, Journal of Business Ethics, 63(3):297-312.

Singer P 2011. Practical ethics. New York, USA: Cambridge University Press.

Solomon J 2007. Corporate governance and accountability. West Sussex, UK: John Wiley and Sons.

Székely F, Thomas A 2012. Governance at South African state-owned enterprises: what do annual reports and the print media tell us? Social Responsibility Journal, 8(4):441-449

Thompson AA, Strickland AJ 2003. Strategic Management: Concepts and Cases. New York, USA: McGraw - Hill Publication.

Thomson LM and Bureau ET 2009. What is corporate governance? From http:/articles.economictimes.indiatimes.com/2009-0118/news/28462497_1_corporate. (Retrieved on 15 June, 2013).

Tota I, Shehu H 2012.The Dilemma of Business Ethics. Procedia Economics and Finance, 3: 555-559.

Van Basten C 2007. Economic regulation of SA's public utilities. From http://www.tips.org.za/files/Economic Regulation_Concept_Paper.pdf. (Retrieved on March 10, 2013).

Van den Berghe LAA, Levrau A 2004. Evaluating Boards of Directors: what constitutes a good corporate board? Corporate Governance: An International Review, 12(4):461-478. 2004.

Vaughn M, Ryan LV 2006. Corporate Governance in South Africa: a bellwether for the continent? Corporate Governance: An International Review, 14(5):504-512.

Vavi Z 2014. The SABC is still far from fulfilling its mandate. From http://www.politicsweb.co.za/politicsweb/view /politicsweb/en/page72308?oid=639727\&sn=marketingweb+detail\&pid=90389\&utm_source=politicsweb+daily+headlines\&utm_c ampaign=6f88d10d15-dhn_june_25_2014\&utm_medium=email\&utm_term=0_a86f25db99-6f88d10d15-130071861.(Received on 3 July, 2014).

Verlaquez et al, Velasquez, Andre, Shanks, and Meyer (1987). What is meant by the term ethics? From http://www.alzheimereurope.org/Ethics/Definitions-and-approaches/What-is-meant-by-the-term-ethics. (Received on 23 April, 2014).

Walker DHT, Sego M 2008. Business ethics and corporate citizenship. New York, UK:Taylor \& Francis.

Werther WB, Chandler D 2010. Strategic corporate social responsibility: Stakeholders in a global environment. London, UK: SAGE Publications,

Zadek S, Evans R, Pruzan P 2013. Building Corporate Accountability: Emerging Practice in Social and Ethical Accounting and Auditing. London, UK: Earthscan Publication. 